\title{
INOVATYVIŲ ERGOTERAPIJOS METODU TAIKYMAS CEREBRINIU PARALYŽIUMI SERGANČIŲ VAIKŲ DĖMESIO KONCENTRACIJOS LAVINIMUI
}

\author{
Elena Barzinskiene் $\dot{1}^{1,2}$, Aušra Adomavičiené $\dot{1}^{1}$, Almeda Kuriené ${ }^{1}$, Natalja Fatkulina ${ }^{1}$ \\ ${ }^{1}$ Vilniaus universiteto Medicinos fakulteto Sveikatos mokslu institutas, \\ ${ }^{2}$ Vaiku ligonine, Vilniaus universiteto ligoninès Santaros kliniku filialas
}

Raktažodžiai: cerebrinis paralyžius, vaikai, dèmesio koncentracija, RehaCom programa, ergoterapija.

\section{Santrauka}

Efektyvi ergoterapijos programa padeda cerebriniu paralyžiumi sergantiems vaikams geriau adaptuotis kasdieniame gyvenime ir gerina jo kokybę. Inovatyvių technologijų stoka reabilitacijoje yra akivaizdi. Tyrimo tikslas - ivvertinti RehaCom programos poveikị cerebriniu paralyžiumi sergančių vaikų dėmesio koncentracijos lavinimui.

Tyrime dalyvavo 52 tiriamieji (8-12m.), vykdžiusieji ambulatorinès reabilitacijos programą Vilniaus universitetinès ligoninès Santaros klinikų Vaikų ligoninès Fizinès medicinos ir reabilitacijos centre 20172018 metais. Tiriamieji atsitiktinès atrankos būdu suskirstyti ị dvi grupes - tiriamają $(n=26)$ ir kontrolinę $(n=26)$. Tyrimo metu buvo vertinama demesio koncentracija, susikaupimas, budrumas. Tyrimo metodai: Trumpas protinès būklès vertinimo testas (toliau - TPBT), Monrealio kognityvinis testas (toliau - MoCA), skaitmenų ir simbolių pakeičiamumo testas (toliau - SSPT), dèmesio koncentracijos testas „Sujunk taškus“, Kortų rūšiavimo testas įvertinti budrumą.

Vertinimas buvo atliekamas reabilitacijos pradžioje ir pabaigoje. Tiriamajai grupei taikyta RehaCom programa kartu su ịprastine ergoterapija, o kontrolinei - ergoterapijos užsièmimas kognityvinių funkcijų lavinimui kartu su ịprastine ergoterapija. Duomenu analizè atlikta naudojant statistinès analizès R commander I386 3.0.2 ir Excel 2010 programas.

Rezultatai. Nustatyta, kad ir tiriamosios, ir kontrolinès grupès vaikų dèmesio koncentracijos rezultatai reikšmingai pagerejjo, nors statistiškai reikšmingai didesnis pokytis nustatytas tiriamosios grupès. Re-
haCom programa yra efektyvus metodas cerebriniu paralyžiumi sergančių vaikų susikaupimo lavinimui. Tiriamosios grupés susikaupimo rezultatu pokytis buvo statistiškai reikšmingas ( $\mathrm{p}=0,004)$, o kontrolinès grupès rezultatai reikšmingai nepakito $(\mathrm{p}=0,06)$. Tiriamosios ir kontrolinės grupės vaikų budrumas pirmojo tyrimo metu statistiškai reikšmingai nesiskyrè. Antrojo tyrimo metu nustatyta, kad vaikų budrumo rezultatai reikšmingai pagerèjo abiejose grupèse, tačiau statistiškai reikšmingai didesnis pokytis buvo tiriamosios grupès.

Išvados. RehaCom programa yra efektyvi cerebriniu paralyžiumi sergančių vaikų susikaupimo lavinimui. Tiriamosios grupès susikaupimo rezultatu pokytis buvo statistiškai reikšmingas $(\mathrm{p}=0,004)$, o kontrolinès grupès rezultatai reikšmingai nepakito $(\mathrm{p}=0,06)$.

\section{Ivadas}

Cerebrinis paralyžius (toliau - CP) yra kompleksinis sutrikimas, kuris paveikia vaiko motorinius gebejimus bei kognityvines funkcijas - dèmesio koncentraciją, susikaupimą [1]. Tai, kas iggyjama ankstyvoje vaikysteje, tampa tolesnio gyvenimo pagrindu. Ankstyvieji metai gali tapti ilgo ir kokybiško gyvenimo pamatu. Kiekvienos šeimos tikslas yra užauginti sveiką vaiką, todèl dèmesys vaikų raidos problemoms gali užkirsti kelią patologiniams modeliams, kurie darytų ịtaką gyvenimo kokybei. CP sergančių vaikų kognityvinių igūdžių lygmuo yra vienas pagrindinių socialinès raidos parametrų. CP paplitimas Lietuvoje ir Europoje pastaraisiais metais gana stabilus, o naujų technologijų atsiradimas ir medicinos pažanga mažina sergamumą. Remiantis $2014 \mathrm{~m}$. Nacionaliniais Norvegijos gimimo registro duomenimis, ištyrus 1764509 naujagimius, gimusius 23-43 savaičių, buvo nustatyta, kad CP diagnuozuojamas 1,8 iš 1000 gimusiųų [2]. Lietuvos statistikos departamento duomenimis, 2003 $\mathrm{m}$. CP buvo diagnozuojamas 2-3,1 iš 1000 naujagimių [3]. 
Remiantis 2016 m. Lietuvos higienos instituto statistikos duomenimis, cerebrinị ar kitą paralyžių turinčių vaikų rodiklis siekia 3,3 iš 1000 . Lietuvos statistikos departamento duomenimis, dažniausiai diagnozuojamas spastinis dvipusis cerebrinis paralyžius sudaro 43 proc., spastinis vienpusis - 33 proc., diskinezinis - 18 proc., ataksinis -6 proc. [4].

Vaikų, sergančių CP, judesių kaitos koordinacija nepakankama. Jiems sunku keisti judesị, padètị ir veiksmą. Šiems vaikams būdingas sulètėjęs sensorinès informacijos apdorojimas, kognityvinių funkcijų sutrikimas $[1,4]$. Ergoterapeutas gali pagerinti cerebriniu paralyžiumi sergančiu vaikų gyvenimo kokybę. Gebejjimas savarankiškai pavalgyti, apsirengti ir nusirengti, laiku ir vietoje pasinaudoti tualetu, maudytis, palaikyti kūno bei artimiausios aplinkos švarą ir tvarką - vieni iš pirmujų vaikystès pasiekimų, kurie padeda sutvirtinti pasitikèjimą savimi ir pasiekti socialinį pripažinimą. CP sergantys vaikai savarankiškumo ịgūdžius ịgyja skirtingai. Šių ịgūdžių atsiradimas ir jų kokybè itin priklauso nuo vaiko funkcinio lygio, pažintinių igūdžių, tèvų pasirengimo ir požiūrio ị vaiką šeimoje [5].

Reabilitacijos tikslas yra sumažinti ligos simptomus ir neigalumą. Pediatrinè reabilitacija turi būti orientuota ị šeimą, kasdienes veiklas, rutiną, apimti instruktavimą, mokymą ir praktiką. Reabilitacijos rezultatas turi būti prasmingas ir vaikui, ir jo šeimai. Itprastos gydymo parinktys, siekiant palengvinti raumenų disfunkciją, apima kineziterapiją, ergoterapiją, medicininę terapiją ir chirurgiją. Ergoterapijos tikslas - padeti lavinti ir ugdyti mąstymą, suvokimą, kognityvines funkcijas, teikiančias pagrindą sergantiems CP ar turintiems kognityvinių funkcijų sutrikimų vaikams lengviau atlikti kasdienę veiklą. [6]. Lavinamujų būdų ịvairove CP sergantiems vaikams labai svarbi, o inovatyviausias metodas šiam tikslui siekti yra RehaCom kognityvinès terapijos programine įranga [7].

RehaCom - kompiuterinè programa, sudaryta iš keliu reabilitacijos programų, skirtų įvertinti, atkurti, palaikyti bei lavinti pažinimo gebejjimus, tokius kaip dèmesio koncentracija, budrumas, atmintis, susikaupimas, regos laukas ir loginis mąstymas. Naujausi tyrimai rodo, kad pažangios technologijos turi efektyvų poveikị pažintinių funkcijų sutrikimų lavinimui $[8,9]$. Tyrime siekiama atskleisti šios programos naudingumą bei efektyvumą ergoterapijos užsièmimų metu.

Tyrimo tikslas - ịvertinti RehaCom programos poveiki $\mathrm{CP}$ sergančių vaikų dėmesio koncentracijos lavinimui.

\section{Tyrimo objektas ir metodai}

Atliktas eksperimentinis aprašomasis intervencinis tyrimas. Tyrimas vyko Vaikų ligoninès, Vilniaus universiteto ligoninès Santaros klinikų filialo, fizinès medicinos ir reabilitacijos skyriuje. Tyrimo laikotarpis 2017-2018 metai.
Tiriamujų kontingentą sudare $52(\mathrm{~N}=52)$ 8-12 metų vaikai, sergantieji CP, dalyvaujantys ambulatorinès reabilitacijos programoje. Grupès sudarytos atsitiktinès atrankos būdu: 1) tiriamoji grupé $(\mathrm{n}=26)$ - dèmesio koncentracijos lavinimas RehaCom programa; 2) kontrolinè grupé ( $\mathrm{n}=26)$ - dèmesio lavinimas įprastinès ergoterapijos užsièmimų metu, pasitelkiant specialias dèmesio lavinimo užduotis. Kiekvienas tiriamasis dalyvavo 10 ergoterapijos užsièmimų, kurių trukmè buvo po 30 min.: $15 \mathrm{~min}$. skirta dèmesio koncentracijos lavinimui ir 15 min. - iprastinei ergoterapijai (toliau - ET). Tiriamuju demesio koncentracija, budrumas ir susikaupimas buvo vertinami du kartus - reabilitacijos pradžioje ir pabaigoje po 10 užsiemimų, t.y. vidutiniškai po 2 savaičių. Iš 52 tiriamujų tyrime dalyvavo 52, iš jų 33 (63 proc.) berniukai ir 19 (37 proc.) mergaičių. Tiriamosios grupès vaikų amžiaus vidurkis buvo $9,8 \pm 1,6$, kontrolinès $-9,4 \pm 1,4$ metai.

Tyrimui atlikti gautas istaigos vadovo sutikimas ir visų vaikų tèvų informuoto asmens sutikimai. Visi tiriamieji dalyvavo tyrime savo noru, jų teisès nebuvo pažeistos, prieš ir po tyrimo tèvai gavo visą reikiamą informaciją. Atliekant tyrimą, etikos taisyklès nebuvo pažeistos, viešujų ir privačiųjų interesų konfliktų nẻra.

Monrealio kognityvinis testas (MoCA) skirtas lengvo kognityvinio sutrikimo vertinimui. Juo vertinamos įvairios kognityvinio funkcionavimo sritys: demesys ir jo koncentracija, vykdomoji funkcija, atmintis, kalba, vizualiniai-erdviniai gebejjimai, sąvokinis mąstymas, skaičiavimas ir orientacija. Skaitmenų ir simbolių pakeičiamumo testas (SSPT) reikalauja reagavimo greičio, nuolatinio dèmesio, vizualių erdvinių ịgūdžių. Atlikdamas šị testą, dalyvis pildo simbolių seriją, tinkamai koduotą per 90 sekundžių. Kuo daugiau užpildytų langelių, tuo geresni rezultatai. Taškų sujungimo testas skirtas vertinti dèmesio koncentraciją. Vertinama, kaip pacientas geba susikaupti ir atlikti paskirtą užduotị. Užduotị sudaro dalinis vaizdas, kurị reikès pabaigti, sujungiant taškus. Taškų skaičius -40 . Vertinama, kiek taškų sujungta per 1 minutę. Didžiausia balų suma - 40. Kortų rūšiavimo testu vertinamas paciento budrumas. Tiriamajam duodama keturiu skirtingų spalvų 30 kortelių kaladè ir vertinama, kiek surūšiuota kortelių per 1 minutę. 1 kortelè - 1 balas. Didžiausia balų suma -30 . Trumpas protinès būklès vertinimo testas (TPBT) - plačiausiai pasaulyje naudojamas formalizuotas kognityvinių funkcijų tyrimo metodas. TPBT paprastai ir greitai ịvertinamos šios kognityvinès funkcijos: orientacija laike bei vietoje; gebejjimas ịsiminti žodžius; trumpalaikė atmintis; dèmesys (skaičiavimas); kalba; vykdomoji funkcija (praksis); rašymas; regos - erdviniai, konstrukciniai gebejimai.

Duomenų analizè atlikta naudojant statistinès analizès $\mathrm{R}$ commander I386 3.0.2 ir Excel 2010 programas. 


\section{Rezultatai}

TPBT nustatyta, kad tiriamoji grupé I tyrimo metu gavo $22 \pm 1,6$ balų. Mažiausias rezultatas buvo 20 , didžiausias 25 balai. II tyrimo metu pasiektas 24,2 balų vidurkis, $\mathrm{SN}$ $\pm 1,1$. Mažiausias rezultatas buvo 23, didžiausias 26 balai. Kontrolinè grupe I tyrimo metu pasiekè 21,9 balų vidurkị, $\mathrm{SN} \pm 1,2$. Mažiausias rezultatas buvo 20 , didžiausias 26 balai. II tyrimo metu pasiektas 23,4 balų vidurkis, $\mathrm{SN} \pm 0,8$. Mažiausias rezultatas 21, didžiausas 25 balai. Nustatyta, kad testas rodo statistiškai reikšmingą pokytį grupèse $p<0,005$ ir tarp grupių $\mathrm{p}<0,0023$ (1 lentelè).

MoCA testu išanalizavus visų tiriamujų duomenis, gautas rezultatas parode, kad tiriamojoje grupejje pagerejimo vidurkis buvo beveik du kartus didesnis, nei kontrolineje atitinkamai - 3,2 ir 1,7 balo. Tiriamosios grupès mažiausias balas I tyrimo metu buvo 17, II tyrimo metu - 21 balas. Tiriamosios grupès I tyrimo metu didžiausias balų skaičius buvo 23, o II tyrimo metu padidèjo 2 balais ir sudare 25 balus. Kontrolinès grupès I tyrimo mažiausias balas 14, o II tyrimo -17 balų. Didžiausias kontrolinès grupes I tyrimo balų skaičius buvo toks pat, kaip ir tiriamosios grupès -23 , o per II tyrimą - 24 balai. Tiriamoji grupé pasiekẻ statistiškai reikšmingą pagerèjimą $(\mathrm{p}<00,5)$. Kontrolinė grupé pasiekè statistiškai reikšmingų rezultatų $(\mathrm{p}=0,007)$. Lyginant tarp pogrupių, rezultatai statistiškai reikšmingai pagerejo $(\mathrm{p}=00,1),(1$ lentelè $)$.

Vertinat tiriamają grupę SSPT testu, rezultatai buvo statistiškai reikšmingai pagerèję tarp I ir II tyrimo, kur p=0,03. Tiriamosios grupés I tyrimo metu mažiausias balų skaičius siekè 18, o II tyrimo metu mažiausias balas buvo padidejęs iki 23, o didžiausias pakilo nuo 46 iki 49. Per I tyrimą vidurkis buvo 34 balai, $\mathrm{SN} \pm 7$. Per II tyrimą vidurkis pasiekè

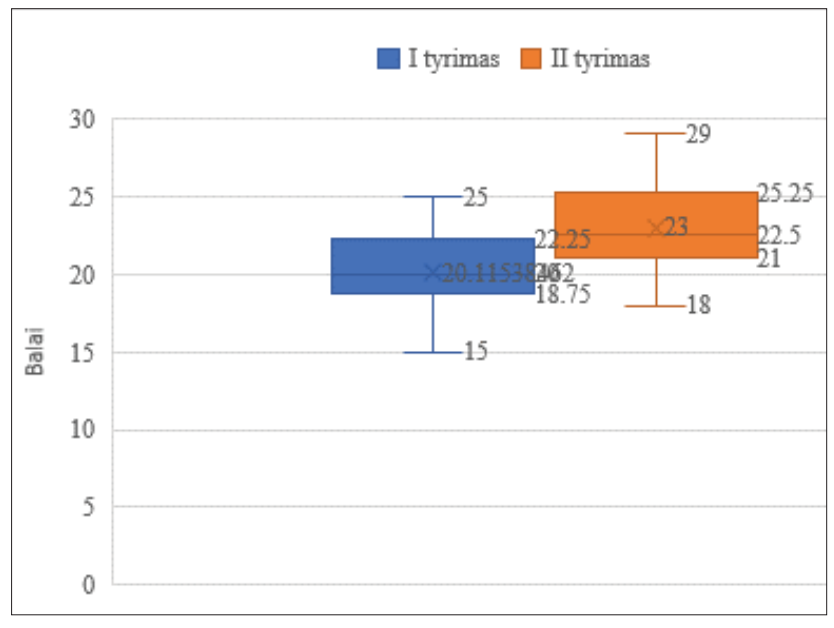

1 pav. Testo „Sujunk taškus“ tiriamosios grupès susikaupimo rezultatai.
38 balus, $\mathrm{SN} \pm 7$ balai (1 lentelè ). Kontrolinès grupès SSPT rezultatai buvo statistiškai reikšmingai pagerèję tarp I ir II tyrimo, kur $\mathrm{p}=0,03$. Tiriamosios grupès I tyrimo metu mažiausias balų skaičius siekè 16, o II tyrimo metu jis pasieké 19, didžiausias nuo 45 padidejo iki 48. Per I tyrimą vidurkis buvo 34 balai, $\mathrm{SN} \pm 7$. Per II tyrimą vidurkis pasieke 37 balus, $\mathrm{SN} \pm 7$ balai (1 lentelè).

Tiriant testu „Sujunk taškus“, tiriamosios grupès rezultatai buvo statistiškai reikšmingi $(\mathrm{p}=0,004)$. I tyrimo metu vidurkis pasiekè 20,1 balo, II tyrimo metu - 23 balus. Mažiausias balų skaičius per I tyrimą buvo 15 , per II - 18 . Didžiausias skaičius padidejo 4 balais, nuo 25 iki 29 (1 lentelè ir 1 pav.).

Kontrolinès grupės pasiekti rezultatai buvo statistiškai ne-

1 lentelè. I ir II tyrimo testų vertinimo rezultatai ir pokytis tarp grupių.

*-statistinis reikšmingumas, kai $P<0,05$; $S N$-standartinis nuokrypis.

\begin{tabular}{|c|c|c|}
\hline \multicolumn{3}{|c|}{ Protinès būklès trumpojo tyrimo vertinimo rezultatai } \\
\hline \multicolumn{3}{|c|}{ Dèmesio koncentracijos pokyčiai (balų vidurkis \pm SN) } \\
\hline & I tyrimas & II tyrimas \\
\hline Tiriamoji grupè & $22 \pm 1,6$ & $24,2 \pm 1,1 *$ \\
\hline Kontrolinė grupė & $21,9 \pm 1,2$ & $23,3 \pm 1,1^{*}$ \\
\hline Pokytis tarp grupių & & $\mathrm{P}=0,0023$ \\
\hline \multicolumn{3}{|c|}{ Monrealio kognityvinių funkcijų testo vertinimo rezultatai } \\
\hline \multicolumn{3}{|c|}{ Dėmesio koncentracijos pokyčiai (balųvidurkis \pm SN) } \\
\hline & I tyrimas & II tyrimas \\
\hline Tiriamoji grupè & $19,5 \pm 1,6$ & $22,7 \pm 1,3^{*}$ \\
\hline Kontrolinė grupė & $19,2 \pm 2,3$ & $20,9 \pm 2,2 *$ \\
\hline Pokytis tarp grupių & & $\mathrm{P}=0,01$ \\
\hline \multicolumn{3}{|c|}{ Skaitmenų ir simbolių pakeičiamumo testo rezultatai } \\
\hline \multicolumn{3}{|c|}{ Budrumo pokyčiai (balų vidurkis \pm SN) } \\
\hline & I tyrimas & II tyrimas \\
\hline Tiriamoji grupė & $34 \pm 7$ & $38 \pm 7 *$ \\
\hline Kontrolinè grupé & $34 \pm 7$ & $37 \pm 7 *$ \\
\hline \multicolumn{3}{|l|}{ Pokytis tarp grupių } \\
\hline \multicolumn{3}{|c|}{ Testo „Sujunk taškus“ rezultatai } \\
\hline \multicolumn{3}{|c|}{ Susikaupimo pokyčiai (balųvidurkis \pm SN) } \\
\hline & I tyrimas & II tyrimas \\
\hline Tiriamoji grupé & $20 \pm 5$ & $23 \pm 3 *$ \\
\hline Kontrolinė grupé & $20 \pm 5$ & $21 \pm 5$ \\
\hline Pokytis tarp grupių & & $\mathrm{P}=0,05$ \\
\hline \multicolumn{3}{|c|}{ Testo „Kortų rūšiavimas“ rezultatai } \\
\hline \multicolumn{3}{|c|}{ Budrumo pokyčiai (balųvidurkis \pm SN) } \\
\hline & I tyrimas & II tyrimas \\
\hline Tiriamoji grupé & $20,1 \pm 2,8$ & $22,2 \pm 2,7 *$ \\
\hline Kontrolinė grupė & $19,9 \pm 2,9$ & $21,4 \pm 2,5^{*}$ \\
\hline Pokytis tarp grupių & & $\mathrm{P}=0,04$ \\
\hline
\end{tabular}


reikšmingi $\mathrm{p}=0,06$. I tyrimo metu vidurkis buvo 20 , II tyrimo metu - 21 balas. Mažiausias balų skaičius per I tyrimą 14, per II -16 balų. Didžiausias balo pokytis tarp I ir II tyrimu buvo 2 balai, nuo 24 iki 26 balų (1 lentelè).

\section{Rezultatų aptarimas}

Pastaraisiais metais daugeja mokslinių tyrimų, kurių metu naudojamos kompiuterinès programos. Teigiama, kad šios programos yra perspektyvios, igalina serganti asmeni jomis naudotis namuose ar gydymo įstaigose, esant ìvairių pažinimo funkcijų sutrikimų: atminčiai, dėmesio koncentracijai, vykdomosioms funkcijoms, orientacijai ir kt. lavinti $[10,11]$. Kompiuterinių programų naudojimas ergoterapijos metu bei namuose mažai Lietuvoje tyrinèta sritis. Yra duomenų, kad jos gali būti sèkmingai naudojamos CP sergantiems ar kitų sutrikimų turintiems vaikams, siekiant juos sudominti ir, parinkus tiksliai orientuotą moduli pagal vaiko galimybes, gabumus, pasiekti geresnių dèmesio koncentracijos lavinimo rezultatų. 2015 metais K. Richter ir kolegos atliko vaikų atminties lavinimo ir demesio koncentracijos RehaCom programa tyrimą. Tiriamajai grupei jie taikè programos pažintinių funkcijų lavinimo bei treniruočių kompleksą, kurio bendra trukmè 9 valandos. Po antrojo testavimo užsienio autorių tyrimai parodè sèkmingai pasiektus statistiškai reikšmingus pažintinių funkcijų lavinimo rezultatus, pagerèjo vaikų darbinè ir fiziologinè atmintis bei dèmesys [12]. 2011 metais F. Mattioli su kolegomis įvertino kompiuterinès mokymo programos veiksmingumą, pasiekę statistiškai reikšmingų dėmesio koncentracijos lavinimo rezultatų. Jų tyrime dalyvavo 150 išsètine skleroze sergančių ambulatorinès reabilitacijos pacientų. Tiriamiesiems taikytas 3 mėnesių trukmès RehaCom programos kursas. Reabilitacijos pabaigoje statistiškai reikšmingai pagerèjo dėmesio koncentracija bei fiziologinè atmintis, nustatytas statistiškai nereikšmingas žodžių ịsiminimo pokytis. Tyrejjai pastebejjo, kad inovatyvių technologijų amžiuje daugèja įvairių kompiuterinių programų, kurios sẻkmingai gali būti naudojamos ir reabilitacijos metu, ir pacientų namuose [13]. Mokslininkai planuoja atlikti išsamesnius tyrimus, kurie tiksliau ir plačiau įvertins kompiuterinių programų poveiki, jų trukmę bei pažintinių funkcijų lavinimo intesyvumą. Lietuvoje bus atliekami tolimesni tyrimai, kurie padès tiksliau nustatyti RehaCom programos poveiki pacientams ergoterapijos užsièmimų metu.

\section{Išvados}

RehaCom programa yra efektyvi CP sergančių vaiku susikaupimo lavinimui. Nustatytas statistiškai reikšmingas $(p=0,004)$ tiriamosios grupès susikaupimo rezultatų pokytis, kai kontrolinès grupès rezultatai reikšmingai nepakito $(p=0,06)$. Ši programa efektyviai lavina dèmesio koncentraciją bei budrumą.

\section{Rekomendacijos}

Programą rekomenduojama taikyti CP sergantiems vaikams bei ịvairių pažintinių funkcijų sutrikimų atvejais, ypač susikaupimo lavinimui. Rekomenduojama ambulatorinès reabilitacijos metu RehaCom programos pagalba atlikti ne mažiau kaip 10 užsièmimų po $15 \mathrm{~min}$. ir daugiau.

\section{Literatūra}

1. Schiariti V, Selb M, Cieza A, O'Donnell M. International classification of functioning, disability and health core sets for children and youth with cerebral palsy: a consensus meeting. Developmental Medicine \& Child Neurology 2015;57(2):149-58.

https://doi.org/10.1111/dmcn.12551

2. Trønnes H, Wilcox A, Lie R, Markestad T, Moster D. Risk of cerebral palsy in relation to pregnancy disorders and preterm birth: a national cohort study. PubMed 2014.

https://doi.org/10.1111/dmcn.12430

3. Prasauskienė A. Cerebrinis paralyžius: medicininiai, pedagoginiai ir socialiniai aspektai. Kaunas, 2011;15-17.

4. Lietuvos sveikatos statistika 2016. Higienos instituto Sveikatos informacijos centras, 2017.

http://www.hi.lt/uploads/pdf/leidiniai/Statistikos/LT sveik stat_health/la2016.pdf

5. Jasaitytė A., Petruševičienė D., Lendraitienė E., Šakalienė R., Rimdeikienè I. Ergoterapijos poveikis vaikų, sergančių cerebriniu paralyžiumi, savarankiškumui. Reabilitacijos mokslai: slauga, kineziterapija, ergoterapija, 2014;2(11):4-9.

https://doi.org/10.33607/rmske.v2i13.689

6. Novak I, Morgan C, Adde L, Blackman J, Boyd RN, et al. Early, accurate diagnosis and early intervention in cerebral palsy: advances in diagnosis and treatment. JAMA Pediatr 2017;171(9):897-907.

7. Karch D, Albers L, Renner G, Lichtenauer N, von Kries R. The efficacy of cognitive training programs in children and adolescents: a meta-analysis. Dtsch Arztebl Int 2013;110(39):643-52.

8. Fernández E, Bringas ML, Salazar S, Rodríguez D, García ME, Torres M. Clinical impact of RehaCom software for cognitive rehabilitation of patients with acquired brain injury. MEDICC Rev 2012; 14(4):32-5.

https://doi.org/10.1590/S1555-79602012000400007

9. Fabre D,Vehier A, Chesnoy-Servanin G, Gouiller N, Thierry D'Amato, Saoud M. From theory to practice: a cognitive remediation program based on a neuropsychological model of schizophrenia. Front Psychiatry 2015;6:169.

https://doi.org/10.3389/fpsyt.2015.00169

10. Amonn F, Frölich J, Breuer D, Banaschewski T, Doepfner M. Evaluation of a computer-based neuropsychological training in children with attention-deficit hyperactivity disorder (ADHD). 
Neuro Rehabilitation 2013;32(3):555-62.

https://doi.org/10.3233/NRE-130877

11. Pereira-Morales AJ, Cruz-Salinas AF, Aponte J, PereiraManrique F. Efficacy of a computer-based cognitive training program in older people with subjective memory complaints: a randomized study. Int J Neurosci 2018;128(1):1-9. https://doi.org/10.1080/00207454.2017.1308930

12. Richter KM, Mödden C, Eling P, Hildebrandt H. Working memory training and semantic structuring improves remembering future events, not past events. Neurorehabil Neural Repair 2015;29(1):33-40.

https://doi.org/10.1177/1545968314527352

13. Mattioli F, Stampatori C, Zanotti D, Parrinello G, Capra R. Efficacy and specificity of intensive cognitive rehabilitation of attention and executive functions in multiple sclerosis. $\mathrm{J}$ Neurol Sci 2011;303(1-2):151.

https://doi.org/10.1016/j.jns.2011.01.006

\section{IMPACT OF REHACOM PROGRAM ON ATTENTION OF CHILDREN WITH CEREBRAL PALSY E. Barzinskienė, A. Adomavičienė, A. Kurienė, N. Fatkulina}

Keywords: Occupational therapy, RehaCom, children, cognitive functions.

Effective occupational the rapy program helps children with cerebral palsy to adapt in daily life and helps to improve his quality. Lack of innovative technologie sin rehabilitation are obvious.

Research purpose was to evaluate the effect of the "Reha Com" program on the development of children with CP concentrations.

Objective wereto evaluate changes in concentration of the children with $\mathrm{CP}$, determine changes in the concentration of the children with $\mathrm{CP}$, investigate changes in the children with $\mathrm{CP}$ vigilance.

Research methods: 52 children (8-12 years old) witch participated in the outpatient rehabilitation program. The research was carried out at the Center for Physical Medicine and Rehabilitation of Children's Hospital of Vilnius University Hospital, Santaros Clinic.

The study assessed on the attention concentration, accumu- lation, and vigilance. Assessment was made at the beginning and at the end of rehabilitation. Participants were divided in two groups: experimental group $(n=26)$ had therapy with RehaCom program and traditional OT and control group $(n=26)$, which had OT for cognitive functions and traditional OT.

Data analysis was performed using the statistical analysis " $R$ commander I386 3.0.2" and Excel 2010 programs.

Results: Assessment of attention of the subjects Mini-Mental State Examination test was followed by a 2.2-point improvement in the treadmill group, while in the control group it was 1.4 point. Besides, Monreal Cognitive Assesment function test was used, which showed that the average improvement in the study group was almost twice as high as in the control group, respectively -3.2 points and 1.7 points.

The results of the Digit Symbol Substitution test showed that vigilance in the tiramide and control groups improved by 5 and 3 points. In the study of the accumulation of the Connect Points test group, the results achieved between the first and the second study improved by 3 points, while the control groups by 1 point. The second test of card sorting was used for the vigilance test. The average improvement in the study group was 2.1 points, while the control group received 1.5 points.

Conclusions: It was found out that concentration of attention of the children of study and control groups significantly improved in both groups, although statistically it was significant higher in the study groups. The "RehaCom" program is an effective method for educating children with Cerebral grouped paralysis, as the change in the concentration of the study group was statistically significant $(\mathrm{p}=0.004)$, and the control group did not significantly change $(p=0.06)$. There was no statistically significant difference in the children's alertness in the study and control group in study I. In II study, the results of children's alertness significantly improved in both groups, but statistically was significantly higher in the experimental groups.

Correspondence to: velene007@gmail.com

Gauta 2020-01-23 